\title{
Medisinsk historie
}

\section{Om klorose og blodfattige jenter på slutten av 1800-tallet}

\section{Sammendrag}

På slutten av 1800-tallet var klorose en sykdomsbetegnelse som ble hyppig anvendt særlig på unge kvinner, i Norge så vel som i Amerika og Europa for øvrig.

Redusert hemoglobinnivå og/eller nedsatt antall røde blodlegemer ble antatt å være klorosens fysiologiske bakgrunn. Klorose var ikke et synonym for anemi, men snarere en underordnet kategori med en symptomatologi som var spesielt knyttet til jenter i puberteten.

I et kulturkritisk perspektiv ble sykdommen lansert som både et degenerasjonsfenomen og som en reaksjon på det moderne livets stress og krav. I løpet av de første tiårene av 1900-tallet reduseres antall diagnostiserte tilfeller betraktelig og etter hvert forsvinner klorose ut fra medisinske fagbøker og artikler.

Det pekes på medisinske, biologiske og ernæringsmessige forhold som skal forklare klorosens endelikt, men det stilles spørsmål ved om denne kulturdiagnosens opphør ikke også kan knyttes nye idéhistoriske strømninger med nye kulturelle normer for kvinnelighet, endret juridisk lovgivning og til en økt politisk forståelse av helsens rolle i samfunnet.

\section{Hilde Bondevik}

hilde.bondevik@stk.uio.no

Senter for tverrfaglig kjønnsforskning

Postboks 1040 Blindern

0315 Oslo

Mange sykdommer har gjennom medisinens historie vært knyttet til farger. Sykdomsnavn som gulsott, røde hunder, grå og grønn stær er velkjente blant folk flest, og legger vi til at «den hvite pest» var et av tuberkulosen tilnavn, at Føllings sykdom gir fiolett urin, at svartedøden var et populært navn på en av de største epidemiene som har rammet menneskeheten og at tanoreksia beskriver unge kvinners paniske angst for å miste sin tilkjempede solbrune farge, får vi et lite spekter med mer og mindre alvorlige, fargerike diagnoser. Til disse kan vi føye den grønne syke klorosen. Denne sykdommen hadde sin viktigste periode mot slutten av det 19 . århundret og omtales gjerne som en av datidens store kulturdiagnoser. Selve navnet kommer av det greske ordet «chloros», som nettopp betyr grønn eller grønngul, og den grønnbleke ansiktsfargen hos pasientene oppfattes som klorosens arketypiske stigma. Pasientene var stort sett unge kvinner.

I Norsk Magazin for Lagevidenskapen fra 1892 kan vi lese følgende i en artikkel basert på en forelesning av den franske legen Pierre Potain (1825-1901): «Mine herrer! Idet vi passerer Sygesalen Piorry, vil De ikke have undladt at lægge Mærke til en ung Kone med blegt, mat Ansig og dekoloreret Hud. Hun har ingen Feber og De vil tænke paa, at der foreligger et Tilfælde af Klorose. Diagnosen af denne Sygdom lader sig som her ofte stille med Lethed. Den er, saa at sige, skrevet paa Patienternes Ansigt») (1). Innskrevet på ansiktet. I form av en farge.

Klorosen kalles også «bleksott», og var en sykdom som i Norge som ellers i Europa rammet alle samfunnsklasser og begge kjønn i siste del av 1800-tallet. Særlig rammet sykdommen unge kvinner i 14-20 års alder fra de bedrestilte familier. Mens klorosen i dag nærmest er et ukjent fenomen, var den en velkjent og utbredt sykdom de siste tiårene av 1800-tallet. Tidvis antok den epidemiske former. Rapporteringer og beretninger fra legers konsultasjonsrom, nerveklinikker, sanatorier, kur- og badeanstalter så vel som fra private hjem vitner om at mange unge jenter var rammet. Klorotikerens dårlige appetitt, tretthet, mageproblemer, ujevne hjerterytme og blekgrønne farge ble med andre ord ikke bare observert av en medisinsk profesjon, men også av et uttall bekymrede foreldre, nære bekjente og en rekke skolelærere. Sykdommen kom også til å spille en rolle i samfunnsdebatten og fungerte som basis for en omfattende kulturkritikk.

Sammen med lidelser som hysteri og nevrasteni kan klorosen karakteriseres som en av det sene 1800-tallets kulturdiagnoser, som også eksponeres i skjønnlitteratur og drama. Flere har for eksempel argumentert for at klorosen opptrer som helt sentralt i plotet i Henry James The Wings of the Dove (1902) (2). I likhet med hysteri kan den også sies å representere en av tidens mest typiske kvinnesykdommer. Både hysteri og klorose kan knyttes til samtidens forestillinger om kvinnelighet og peker også mot spennet og tvetydighetene i forestillingene. Både hysteri og klorose er således sykdommer som forteller mye om sin samtid.

Den hyppig innrapporterte forekomsten av kvinnesykelighet rundt forrige århundreskiftet er behørig analysert og beskrevet og satt i sammenheng med kvinners marginaliserte sosiale posisjoner så vel som diagnostiske og teknologiske nyvinninger $(3,4)$. Tidlig på 1900-tallet endrer dette bildet seg, og mye tyder på at unge kvinner fremstår som friskere enn bare noen tiår tidligere. Dette gjelder ikke minst i forbindelse med klorosen, som rundt 1920-30 forsvinner fullstendig. Her gjør selvsagt en rekke medisinske, biologiske og ernæringsmessige forhold seg gjeldende, knyttet blant

\section{Hovedbudskap}

- Sammen med hysteri og nevrasteni kan klorose eller bleksott karakteriseres som en av det sene 1800-tallets store kulturdiagnoser

- Klorosen ble i denne perioden forstått som en anemisykdom som først og fremst rammet unge jenter

- Symptombildet var omfattende, med blekhet, avmagring og tretthet som særlige karakteristiske kjennetegn

- Rundt 1920-30 forsvinner klorosen som sykdomskategori 
annet til bedrede sosiale og økonomiske forhold. Imidlertid kan vi stille spørsmål ved om disse endringene ikke også kan knyttes til idéhistoriske strømninger med nye kulturelle normer for kvinnelighet, nye juridiske lover og til endret politisk forståelse av helsens rolle i samfunnet.

\section{Norske bidrag}

Innenfor en norsk kontekst er tilgangen til materiale om klorosen begrenset, da oversiktlige og gode nasjonale sykestatistikker ikke finnes. Det er derfor vanskelig å oppnå et fullgodt bilde av sykdommens utbredelse i Norge i siste halvdel av det 19. århundret. En gjennomgang av medisinske tidsskrifter, medisinalberetningene, prospekter og oversikter fra sanatorier, kur- og badeanstalter, som Sandefjord kurbad, Eidsvoll kurbad, Grefsen sanatorium, St. Olafs Bad paa Modum, viser imidlertid at klorose hadde sin utbredelse også i Norge, og at et betydelig antall personer diagnostisert med klorose er blitt behandlet på slike steder (5).

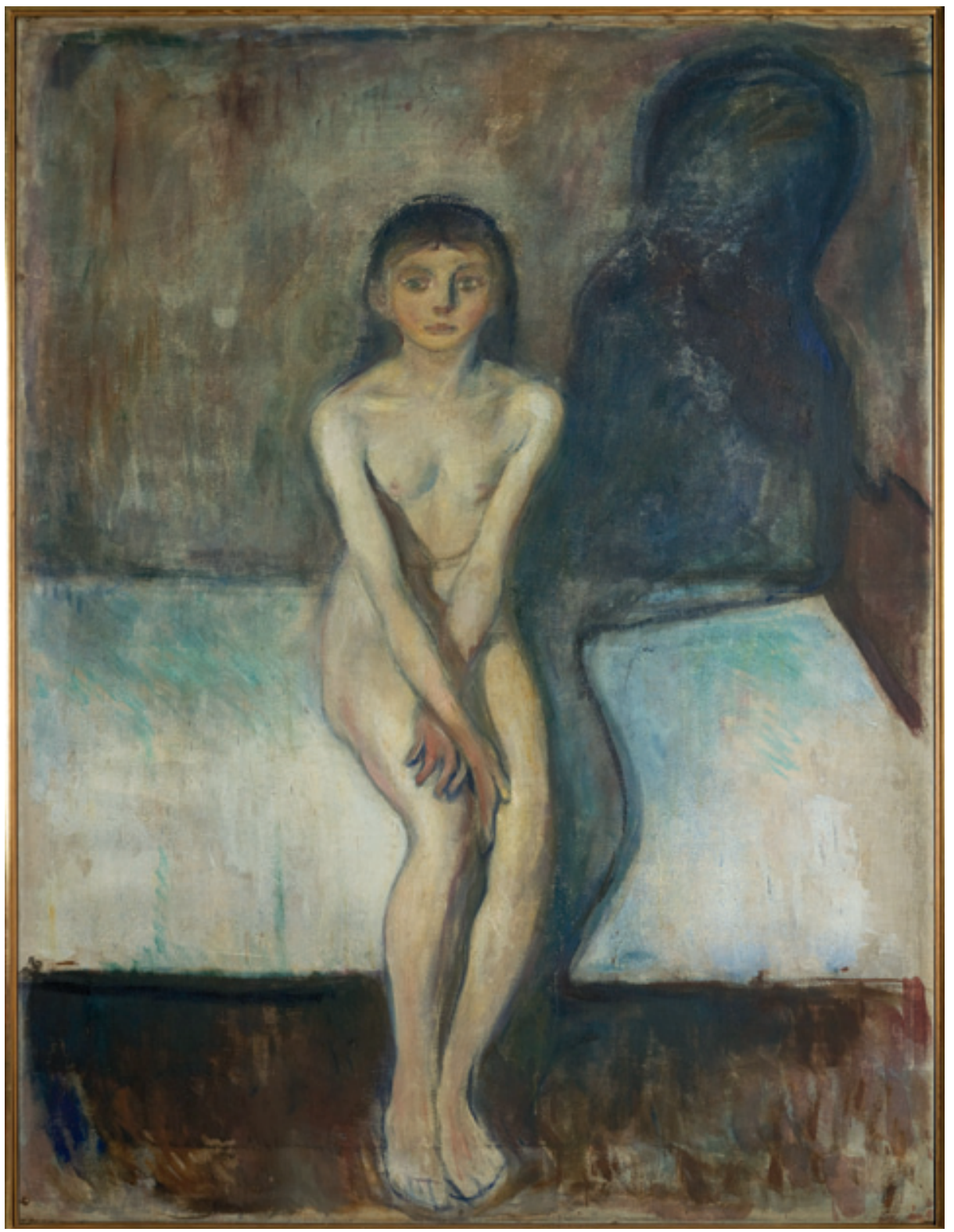

På Eidsvoll kurbad var for eksempel klorosen «de tvende sidste Aar ligesom för været blant de beste repræsenterede» (5). På Sandefjord kurbad befant det seg i perioden 1876-78 flest behandlede - og flest helbredede - i kategorien «Chlorose og Anæmi» (6). I B.C. Vedelers lærebok Kvindens Sygdomme fra 1875 kan vi blant annet lese om klorosen i forbindelse med amenorrhea (7). Og Edvard Bull - Ibsens livlege - påstår i foredraget $O m$ kvindens helbred fra 1886 at det særlig er «blegsot» (sammen med «nervesvaghed») som medvirker til at mange unge kvinner lider av mindre god helbred (8). I 1896 ble sykdommen dessuten gjenstand for en omfattende doktorgrad. Den praktiserende bergenslegen Sigvard Madsen, som også er kjent for å stå bak opprettelsen av et kysthospital for tuberkulosepasienter på Vestlandet i 1893 (og et nytt i 1897), skriver i forordet til doktorgradsavhandlingen $\mathrm{Om}$ klorose og dermed beslagtede sykdomme (1896) følgende:
«Det er neppe mange Sygdomme, om hvilket der i Tidenes Løb har vært skrevet saa meget om som Klorosen. Men der er paa den annen Side heller ikke mange Sygdomme, om hvilket det kan siges, at Opfatningen af deres Væsen og Natur har skiftet saaledes, som Tilfældet er med denne Sygdom.» (9).

Madsen belyser her hvor omskiftelig også medisinsk kunnskap kan være, og hvor vanskelig det er å gripe en sykdomsenhet både historisk og i egen samtid.

Medisinhistorien viser på sin egen måte hvordan enkelte diagnoser kommer og går, og hvordan medisinsk kunnskap alltid er historisk situert. I en periode kan en sykdom være på alles lepper, mens den kort tid senere er glemt. Madsens avhandling om klorose peker videre på sykdommens omfattende symptomatologi, dens helhetlige omfang:

«Dette Forhold er imidlertid ikke saa vanskelig at forstaa, naar man erindrer, at Klorosens Symptomatologi i Grunden omspænder det hele menneskelige Legemet. Det gives neppe det Organ, som ikke kan være sygeligt angrebet under Klorosen. Hjertet og Karsystemet, Lungerne, Digestionsorganene, Nervesystemet, Urogenitalorganene, alle kan de frembyde sygelige Symptomer. Og saa har vi Blodet med de Forandringer, som der findes, og endelig den lidende Tilstand, hvori Legemets almindelige Ernæring synes at befinde sig.» (9).

Sykdommens interne metamorfoser inngår i denne beskrivelsen. Og kanskje er det ikke tilfeldig at av alle organene klorose kan ramme, så nevnes hjertet først. Ikke bare oppfattes hjertet gjerne som det viktigste av alle organer, det er også det organ som assosieres til emosjoner, følelser, affekter og kjærlighet, som på sin side gjennom århundrer igjen har vært knyttet til forestillinger om det kvinnelige. Klorosen inngår i dette bildet. Vitenskapen sto på sin side rådvill: Sykdommens vesen lot seg altså ikke bestemme. Madsen slår fast:

«Intet under, at det faldt vanskelig at finde Enheden i Mangfoldigheden; intet Under, at Forskerne i Tidens løb fæster Opmærksomheden snart paa den ene, snart paa den anden Symptomgruppe og alt efter Tidens Smag og Retning søgte Grundaarsagen til Sygdommen i dette eller hint Organ eller Organsystem.» (9).

Fra dette gjør Madsen to slutninger, den

Det var særlig unge kvinner i puberteten som ble rammet av klorose. Blant klorosens karakteristiske symptomer var blekhet, tretthet, tristhet og avmagring - alle kjennetegn som Munchs maleri Pubertet også illustrerer. Edvard Munch: Pubertet, 1894, olje på ugrundert lerret, 149 × 112 $\mathrm{cm}$, Munch-museet. (C) Munch-museet/Munch Ellingsen gruppen/BONO 2009. Foto (C) Munchmuseet 


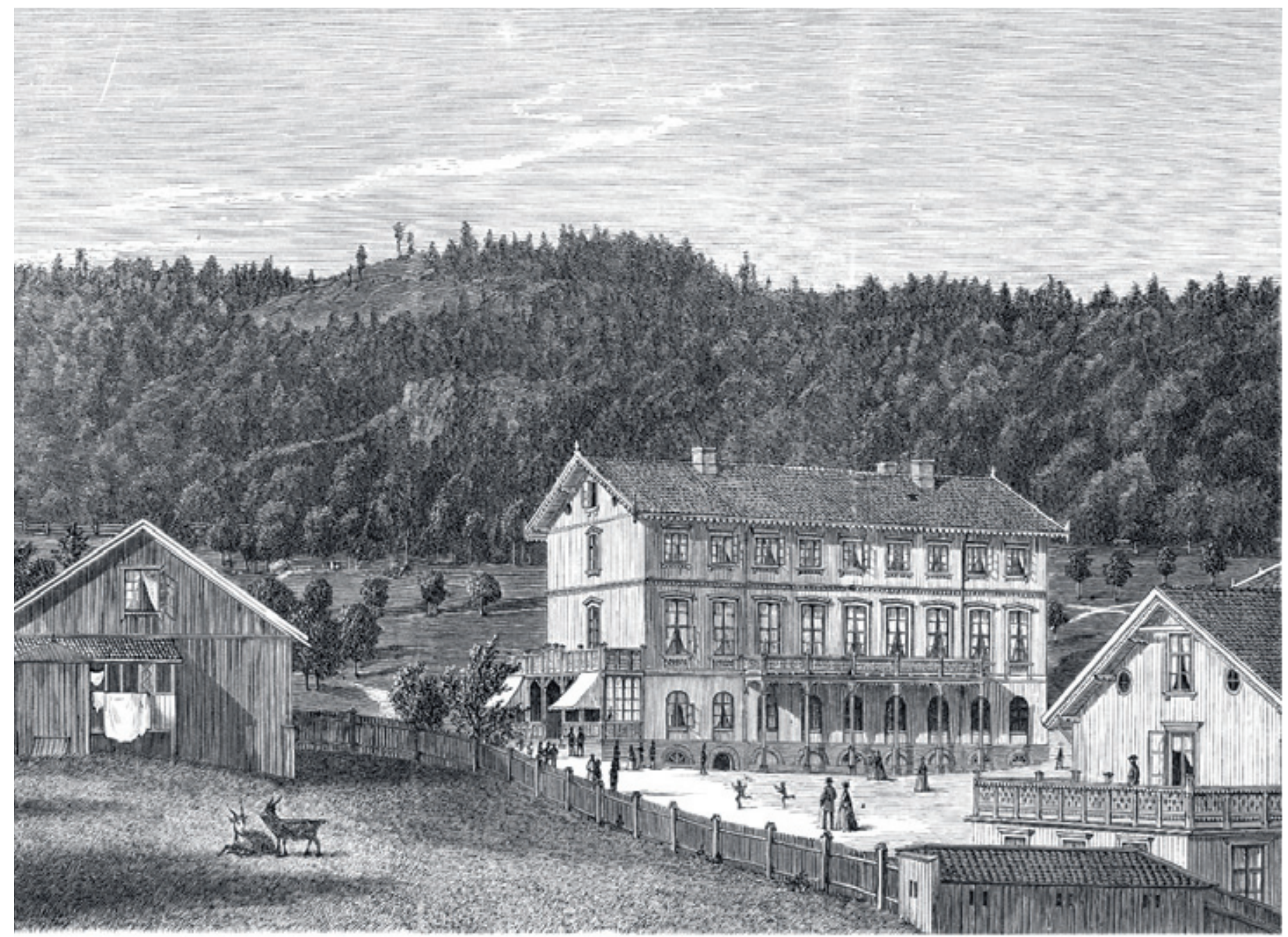

Grefsens Vandcuuranstalt ved Christiania.

De siste tiårene av 1800-tallet var mange klorotiske pasienter innlagt på norske kurbad og sanatorier, blant annet her på Grefsen kurbad. Utlånt av Inger Beate Larsen

ene biomedisinsk, den andre sosialmedisinsk. Først påpeker han nemlig at det dreier seg om en blodsykdom:

«Vistnok tør vi tro, at vor Tid har fundet det Rette, naar den antager, at Blodet er det primært lidende ved en typisk Klorose, og naar den desuden tillige almindelige formener, at det er den sygelige Tilstand i Blodet, som betinger alle de øvrige sygelige Symptomer hos den klorotiske Patient.» (9).

Dernest påpeker han sykdommens smittefare, dens tendens til å spre seg rundt om i samfunnet:

«[...] thi Klorosen tør siges at være en Samfundssygdom med Tendens til Udbredning; og den Skade, den forvolder saavel for den enkelte Individ som for hele Samfund, saavel direkte som indirekte, er ikke ringe.» (9)

Vi har med andre ord å gjøre med en sykdom som stadig flere i franske Pierre Potains og norske Sigvard Madsens samtid rammes av, en sykdom som forårsaker stor lidelse og som har sine karakteristiske og lett gjenkjennelige kjennetegn. Men også en sykdom hvis vesen og natur fremstår som vanskelig å forstå og å avgrense, og som etter hvert forsvinner helt. I ettertid har forklaringene på dens oppkomst og endelikt befunnet seg i spennet mellom troen på at klorosen var en virkelig sykdom og troen på at den var en slags kulturbetinget atferd relatert til et viktoriansk univers.

I det følgende søker jeg ikke å forklare hva klorose egentlig var med termer hentet fra dagens medisinske forståelsesrammer. Snarere vil mitt historiserende blikk på sykdommen være knyttet til spørsmål som: Når oppsto klorosen som sykdomsbegrep? Hva besto de sykelige forandringene $\mathrm{i}$ blodet av, og hvordan ble de forklart? Hvem fikk denne diagnosen? Hvor utbredt var den? Og ikke minst når tappes sykdomsbegrepet for dets innhold og referanse? Hvilke mytologiske lag er det tale om?

\section{Forklaringsmodeller}

Til forskjell fra for eksempel nevrasteni, men i likhet med hysteri, har klorose en lang historie. Beskrivelser av sykdomstilstanden opptrer i medisinsk så vel som i annen litteratur lenge før 1800-tallet og har tråder tilbake til antikken og det hippokratiske tekstkorpuset. Selve termen klorose ble første gang anvendt av den franske legen Jean Varandal fra Montpellier for å beskrive en bestemt tilstand i et skrift fra 1619. Denne termen kan igjen knyttes til betegnelsen «jomfruenes sykdom», «kjærlighetens sykdom», «den grønne sykdom», «hvit feber» og fra midten av 1800-tallet også til kategorien hypokrom anemi. Disse navnene illustrerer at førmoderne diagnostiske kategorier gjerne ble knyttet til farger, og Varendal selv brukte begrepene klorose, hvit feber og jomfruenes sykdom om hverandre. Det var imidlertid den engelske legen Johannes Lange (1485-1566) som litt tidligere beskrev et bestemt og enhetlig sykdomsbilde, som fanges opp i klorosebegrepet. Selv anvender Lange termen «morbus virgineaus» (1554) eller «jomfruenes sykdom». Etter hvert ble gjerne «klorose» anvendt $\mathrm{i}$ en medisinsk og klinisk sammenheng, mens «den grønne sykdommen» lever sitt videre liv i en mer folkelig og populærkulturell sammenheng. I sitt encyklopediske essay om blodsyk- 
dommer skriver for eksempel Alfred Stengel (1868-1939) at «the greensickness» må regnes som «the popular name» mens «chlorosis» anvendes som «the technical name» (10). Ifølge den klassisk orienterte medisinhistorikeren Helen King knytter klorosen seg først og fremst til en tekstlig og litterær fortolkningstradisjon, der symptombildene ble utviklet i forhold til tekstlige autoriteter snarere enn til en observerbar realitet $(10,11)$.

Mens det kliniske symptombildet i klorosens historie har vært ganske konsistent og stabilt, har etiologien og oppfatningen av sykdommens vesen vist større variasjon, og spenner særlig mellom et fokus på menstruasjonsforstyrrelser, nervøsitet og blodmangel. Det skilles gjerne mellom tre hovedteorier om sykdommens grunn og «opstaaen»: Den første og eldste er den genitale teorien, dernest kommer teorien om det nervøse årsaksgrunnlag, og endelig den digestive teorien.
På slutten av 1800-tallet ble klorosens fysiologiske bakgrunn i hovedsak forstått som redusert hemoglobininnhold og/eller redusert antall røde blodlegemer. Sykdommen skilte seg imidlertid fra andre anemiformer og ble gjerne oppfattet som en underkategori av anemisykdommer, med en egen symptomatologi, som særlig knyttet an til unge kvinner: blekhet, spiseforstyrrelser og uregelmessige menstruasjoner. På denne tiden var det kjent at tilførsel av jern hadde god effekt på pasientene. I en artikkel om klorosens etiologi, patogenese og terapi fra 1881 kan vi lese: «Der gives neppe et Punkt i den hele Terapi, om hvilket der for Nærværende er saa liden Meningsforskjellighed som om Jernets eminente Virkning av Klorose» (12). 15 år senere skriver Sigvald Madsen at jernets virkning er så kjent og uttalt at han $\mathrm{i}$ avsnittene om terapi først bare bekrefter den allmenne oppfatningen før han diskuterer andre terapeutiske og sosialmedisinske virkemidler.
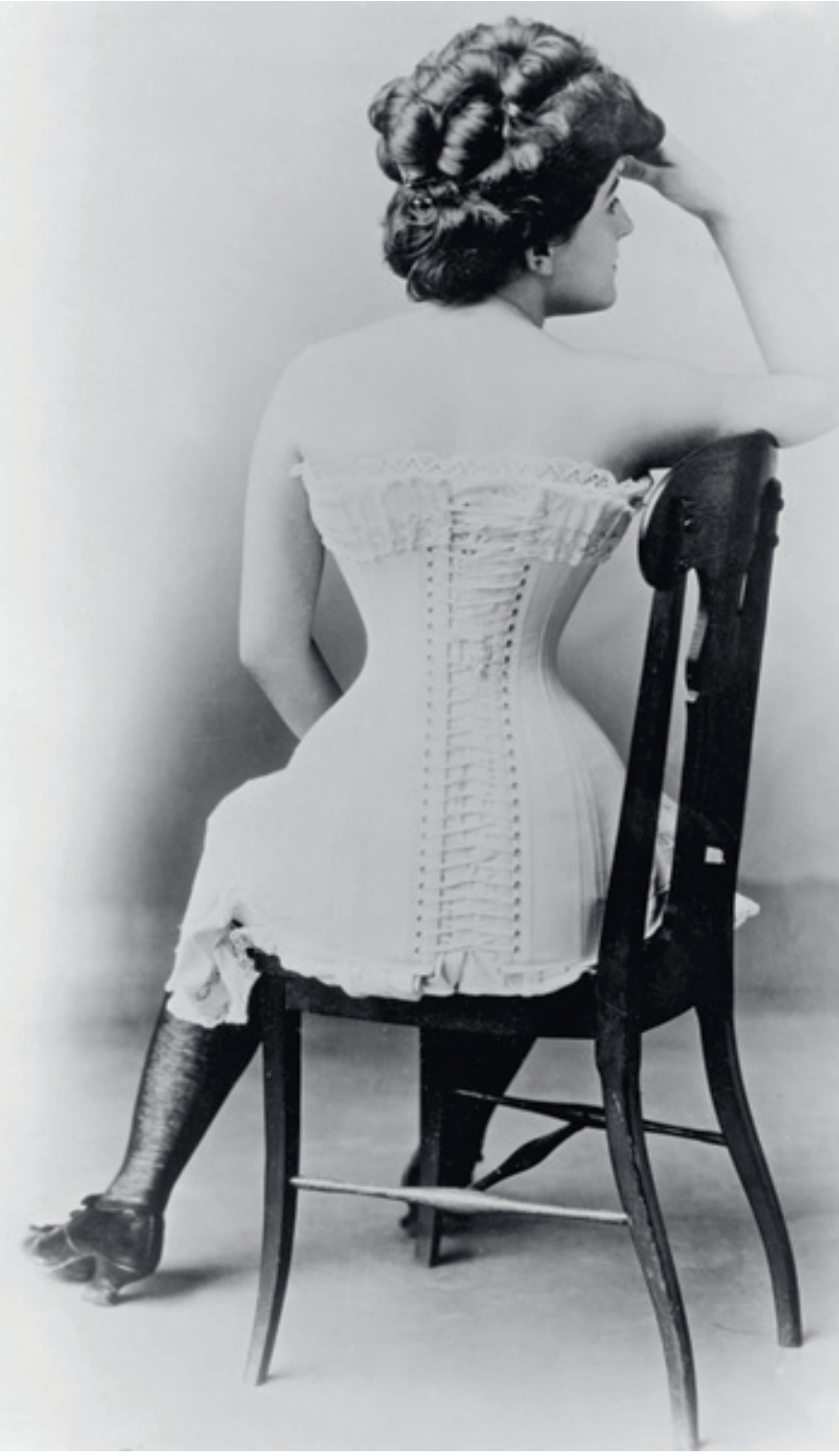

Korsettet har vært trukket frem som en innretning som i særlig grad kunne fremprovosere klorose. Illustrasjonsfoto (c) Bettmann/Corbis/SCANPIX

I løpet av andre halvdel av 1800-tallet ble det utviklet ny teknologi som skulle få betydning for diagnostisering av klorose. En rekke tester for å måle hemoglobininnholdet i blodet så dagens lys, og etter hvert ble både hemoglobinometere og hemocytometere brukt diagnostisk. Slike tester ble imidlertid ikke del av en etablert diagnostikk før utover på 1890-tallet da de ble innført på en rekke sykehus (13-16). Tidligere baserte diagnostiseringen av klorose seg følgelig på forholdsvis vage symptombilder, som i tillegg til blekhet, spise- og menstruasjonsforstyrrelser også inkluderte tretthet, tristhet, hodepine, hjertebank, pustebesvær, depresjoner - symptomer som hundrevis av sykdommer kan produsere.

Det fantes imidlertid en rekke ulike forklaringer på og delte meninger om dens årsaker også i siste halvdel av 1800-tallet forklaringer som også går over i hverandre. Disse kan i hovedsak kategoriseres i tre ulike modeller: en miljømessig, en biologisk-konstitusjonell og en moralsk (3).

Når det gjelder miljøets innvirkning, pekes det blant annet på skadelig opphold i dårlig ventilerte og opplyste rom, for jentene fra arbeiderklassen i kombinasjon med dårlig ernæring og kost, for borgerskapets barn i kombinasjon med studier og manglende mosjon samt slankedietter og bruk av korsett.

De biologisk-konstitusjonelle faktorer dreier seg først og fremst om at klorose er en form for anemi, som gjerne relateres til menstruasjonen, underlivet og nervesystemet. Samtidig omtales også klorosen som et degenerasjonsfenomen og en kulturbetinget sykdom. Den blir et slags symptom på overanstrengelse og en reaksjon på det moderne livets krav og strevsomhet.

Men klorosen ble også satt i sammenheng med, og kunne dessuten forverres av, et vidløftig liv: et utstrakt selskapsliv, dans, romanlesing, erotiske fantasier og dekadanse mer generelt. Slik åpner diagnosen for at moraliserende formaninger inngår i forklaringene på sykdomstilstanden og blir retningsgivende for behandlingen.

Mange antok dessuten at kronisk klorose kunne forårsake en rekke sekundære tilstander, som underlivssykdommer, tuberkulose, hjerteproblemer, magesår, nervesykdommer, nevrasteni, hysteri og sinnssykdom. Den kunne også være en sekundær tilstand av de samme lidelsene. Årsaksforholdene kunne med andre ord gå begge veier: klorose ble både betraktet som en årsak til hysteri og som antatt forårsaket av hysteri.

\section{Sykdomsbegrep og etiologi}

Vender vi oss igjen til Madsens avhandling, kan vi lese at de fleste $i$ hans samtid er enige om å betrakte klorose som en primær blodsykdom, som utvikler seg, i alle fall tilsynelatende, spontant på arvelig eller disposisjonell basis hos unge jenter i puberteten. 
Etter en gjennomgang av en rekke forfatteres mer eller mindre sammenfallende oppfatninger konkluderer han selv med følgende:

«Efter min Opfatning betegnes Klorosen bedst som en primær Anæmi med som i Regel temmelig konstante Forandringer i Blodet, der særlig angriper Kvinden i Udviklingsalderen, uden dog at være absolut bunden til denne Alder og det kvindelige Kjøn.» (9).

Når sykdommen opptrer uregelmessig i forhold til dette, foreslår Madsen å føye til supplerende betegnelser, som «Gutteklorosen, den tardive Klorose, den dyspeptiske Klorosen», slik det blant annet ble gjort i fransk medisinsk litteratur. De mest karakteristiske og konstante trekk i klorotikerens blod er sterkt uttalt hemoglobinfattigdom sammen med nedsettelse av de røde blodlegemenes antall samt forøkelse av hematoblasterne (9). Madsen viser til samtidens skjematiske kategoriseringer av anemier: «1) den simple Anæmi, 2) den progressive perniciøse Anæmi og 3) Klorosen», men han diskuterer også at slike inndelinger ikke er tilfredsstillende og at grensene mellom dem og mellom primære og sekundære tilstander ikke alltid er like tydelig. Klorosen tilskrives hele fire intensitetsgrader: en lett form, en middels form, en intens form og en ekstrem form for klorose (9).

I avsnittet «Prædisponerende Aarsager» diskuterer Madsen forholdet mellom en medfødt disposisjon og sykelig anlegg hos en av foreldrene, og særlig finner han at tuberkulose står i et kausalt forhold til klorosen. Andre sykdommer hos foreldre er blant annet syfilis, alkoholisme, nervøse lidelser (særlig hysteri) samt revmatisme og gikt. Mange av disse sykdommene vil imidlertid også ramme den klorotiske pasienten. Han konkluderer videre med at det er klorosen som bidrar til at nervøse symptomer får anledning til å utvikle seg, snarere enn omvendt. Disposisjon knyttes først og fremst til direkte og indirekte arv fra foreldre, men i noen tilfeller antas den å være ervervet i tidlig barndom. Hygiene, underernæring, mangel på lys og frisk luft, overdreven sportslighet og snøreliv eller korsett diskuteres også, og særlig spiller ernæringsmessige forhold og den utstrakte bruken av korsettet ifølge Madsen en betydelig rolle som determinerende årsaker i forhold til klorosen. Misbruk av kaffe (særlig hos arbeiderklassen i byene), formiddagssjokolade og teselskaper, ball og soireer (særlig blant de bedrestilte klasser) inngår i dette bildet. Menstruasjonsforstyrrelser betrakter Madsen som sekundære ved klorosen, ikke som et etiologisk moment i seg selv (9). Når sykdommen særlig rammer unge kvinner, knyttes det til tanken om at kvinnenes blod i denne perioden er forholdsvis fattigere på hemoglobin enn mannens, samtidig som menstruasjoner stadig gir anledning til et tilbakevendende blodtap (8).

\begin{tabular}{|c|c|c|c|c|c|}
\hline$\AA r$ & Guttebarn & Menn & Jentebarn & Kvinner & Totalt \\
\hline 1881 & 327 & 544 & 1295 & 6660 & 11602 \\
\hline 1890 & 896 & 2048 & 2606 & 15410 & 21162 \\
\hline
\end{tabular}

Flere av disse forholdene blir for øvrig også tatt opp av Edvard Bull ti år tidligere. I et avsnitt om kvinners klesdrakt og helbred omtaler han korsettet som en pervers innretning, som blant annet hindret de unge jentenes bevegelsesutfoldelse og oksygenopptak (8).

\section{Utbredelse og forklaringer}

Men hvor mange led egentlig av klorose i Norge? Hvor utbredt var lidelsen? Under tittelen Klorosens Hyppighet og Forekomst hos os skriver riktignok Sigvard Madsen at det er vanskelig å danne seg et fullstendig bilde av lidelsens hyppighet. Dette blant annet fordi bleksott og anemi er slått sammen i de offisielle listene over kroniske sykdommer, og at medisinalstatistikken er usikker. Ifølge Madsen bør uansett over halvparten av de som er oppført under rubrikken «Blegsot og Anæmi» oppfattes som klorotikere.

De statistiske oversiktene gjengitt i Madsens avhandling viser nær en fordobling i antall innrapporterte tilfeller for tiåret 1881-90. Antallet rammede var langt høyere hos henholdsvis jentebarn og kvinner enn hos guttebarn og menn (tab 1). Han refererer også til en undersøkelse av sunnhetstilstanden i de høyere gutte- og pikeskoler, som viser at det er $4,7 \%$ av gutteelevene som led av bleksott og anemi, mens hele $19 \%$ av jentene led av samme sykdom. Madsen antar altså at halvparten har en kloroseform for anemi. Selv undersøkte han over femårsperioden 1888-92 en gruppe barn av de av «Kommiteen for Folkeskolebørns Ferieophold paa Landet fra Bergen udsendte Børn». Det fremgår at 140 av 188 piker led av anemiske symptomer, altså over $75 \%$, mens 54 gutter av 138 hadde liknende symptomer, det vil si $39 \%$. Den sterke kvinnelige overrepresentasjonen i forhold til menn bekreftes ikke bare av statistikker fra våre naboland (Sverige), men også av andre internasjonale statistikker $(3,14)$.

Et annet interessant forhold som fremkommer er at lidelsen like hyppig rammer «Arbeiderbefolkningen som blant de fra bedre stillede Klasser», og at kvinner i landdistriktene rammes i like stor grad som de i byene. I en gruppe på 65 tilfeller av klorose hos kvinner i 16-25 års alder registrerte Madsen 23 tilfeller blant «de bedre stillede klasser» og 42 blant de med arbeiderklassebakgrunn. Han refererer også til andre norske leger som hadde funnet et liknende forhold. Her opereres det med tre kategorier klorotiske kvinner: «1. Klasse frøkner; 2. Klasse Jomfruer (Butikk-, Syog Husjomfruer) og til 3. Klasse Tjenestejenter», hvorav den siste klassen utgjør den største gruppen klorotikere. Selv om det ikke er mulig å generalisere og trekke bestemte slutninger fra dette beskjedne tallmaterialet, er det bemerkelsesverdig. I klorosens historiografi er denne lidelsen oftest blitt oppfattet som noe som særlig rammer borgerskapets og overklassens kvinner, ikke arbeiderklassen, og befolkningen $i$ byene i større grad enn $i$ landdistriktene. Dette er medisinhistorikeren Edward Shorter ut fra sitt statistiske materiale skeptisk til, og det foreliggende materialet trekker altså i samme retning (14). Klorose var like fullt en svært vanlig sykdom i perioden. Uavhengig av epidemiologiske forhold finnes det ifølge Madsen ingen annen kronisk sykdom som forekommer så hyppig, når ventrikkelsykdommer unntas.

\section{Tap av innhold og referanse}

På begynnelsen av 1900-tallet ser vi en betydelig reduksjon i antall diagnostiserte pasienter. I perioden 1920-30 forsvinner klorosen ut fra medisinske statistikker og fagmedisinske tekster. Hvorfor? Forklaringene er mange, og de er av både medisinsk, miljømessig og kulturell art. I internasjonal litteratur pekes det blant annet på utviklingen av bedre diagnostikk og demarkasjon i forhold til andre lidelser, for eksempel tuberkulose. Herunder var også mer avanserte tester for å måle hemoglobininnhold og celleantall, og i det hele tatt en stadig bedre utviklet medisinsk teknologi og endrede diagnostiske klassifiseringssystemer. Det dreier seg også om en tydeligere biomedisinsk forklaringsmodell, der symptomkomplekset defineres som anemi og der sammensatte forhold knyttet til kjønnsspesifikk fysiologi, psykologi og livsstil i større grad kan holdes utenfor. Tidspunktet falt dessuten sammen med etableringen av hematologi som fag, og det kan se ut som om klorosen så å si innordnet seg og ble oppløst innenfor den overordnede kategorien anemi. Den generelle bedring i sosiale forhold og utvidede sosialmedisinske tiltak (kroppsøving og hygiene) samt utbredelsen av ernærningskunnskap, herunder kosttilskudd og jernbehandling, antas også å ha spilt en avgjørende rolle. I ettertid har man særlig pekt på opphevelse av jernmangel gjennom bedre ernæring, færre sultedietter blant overklassens jenter, mindre bruk av laksermidler og årelatinger og at korsett ikke lenger var moderne. 
Forandringer i de diagnostiske klassifiseringssystemene, generell bedret ernæring og helse kan nok ikke alene forklare klorosens endelikt, og vi skal avslutningsvis utvide perspektivet og peke mot noen flere forhold uten at klorosens gåte av den grunn kan sies å være løst. I parentes bemerket er det flere kommentatorer som påpeker at klorosens karrierefall er et større mysterium enn dens epidemiske topp (14-16).

Da klorose begynte å få økt oppmerksomhet rundt 1880 og ble medisinsk og sosialt legitim, trakk den trolig til seg en rekke symptomer og uklare sykdomsbilder som tidligere savnet tilhørighet. Som Karin Johannisson tematiserer, spredte klorosen seg dessuten epidemisk omtrent samtidig som den gestaltes som en kulturell sykdom og en kvinnesykdom (3). Den ble i tillegg svært aktuell i forbindelse med de store skoledebatter i siste halvdel av 1800-tallet $(13,14)$, hvor ungdommenes helsetilstand ble gjenstand for stadig flere undersøkelser og hvor særlig unge jenters skolegang og utdanning var et stridstema i store deler av Europa og i USA. Teser om overanstrengelse utgjør viktige omdreiningspunkter i disse debattene, likeledes diskusjoner om forholdet mellom intellektuell, fysisk og moralsk fostring. Institusjonaliseringen av det nye sykdomsbildet gikk med andre ord parallelt med skoledebattene, men ble også koblet til hele kulturdebatten og til spørsmålet om hvorvidt sivilisasjonen var på rett vei eller mot en generell moralsk og fysisk degenerasjon. Helen King bemerker på sin side at det alltid har vært en betydelig kreativitet rundt sykdomsbildet der man i stor grad har konstruert unge jenters pubertet, menstruasjon og jomfrulighet til å være et problem og foreslått en terapi, nemlig ekteskapet $(10,11)$. Ifølge King fremstår ekteskapet som det terapeutiske midlet som i løpet av klorosens lange historie har vært mest konstant. Slik føyer klorosens karriere seg inn i et større politisk og kulturelt bilde der fremveksten av en åpnere ekteskaps-, familie-, utdannings- og arbeidslivsstruktur rundt århundreskiftet, sammen med en orientering mot sunnere og mer vitalistiske kroppsidealer, kanskje kan inngå i forklaringene på klorosens endelikt.

\section{Kjønns- og kroppsidealenes tvetydighet}

Det er interessant å se hvordan kropps- og skjønnhetsidealene endrer seg med tiden, og hvordan slike motepregede estetiske preferanser ofte har usunne konsekvenser. Enda mer interessant er det når dette sammenfaller med sykdomsbilder: Blekhet og tanderhet kunne på den ene siden være ettertraktede egenskaper, et uttrykk for fornemhet, dannelse, et følsomt indre liv samt borgerlig klassetilhørighet og frihet fra utendørs arbeid. Faktisk kunne et «snev av bleksott», nærmest være et slags statussymbol. Klorosens sykdomsmytologisering knytter først og fremst an til et borgerlig univers. På den annen siden kunne blekhet og overfølsomhet tolkes medisinsk som symptomer på lidelser som blant annet klorose, nevrasteni, tuberkulose, ulike krefttyper og infeksjoner. Det er også interessant å fastslå at det stikk motsatte kroppsestetiske ideal i våre dager, med solbrun hud og atletisk kroppsbygning, kan knyttes til sykdomstilstander, som unge jenters avhengighet av solbruning (tanoreksi) samt de mange psykiske og fysiske konsekvenser av idealet om slanke eller muskuløse kropper.

Det har også vært påpekt at klorosens symptomer har sine paralleller i våre dagers patologier, som for eksempel anoreksi som for øvrig navngis rundt 1870 . Dens avmagring, manglende appetitt og uregelmessig menstruasjon gjør at det blir fristende å avlese kulturelle koordinater i materialet. Så lenge vi fastholder fortolkningsrammer som knytter det feminine til svakhet, sensibilitet, emosjonalitet, passivitet og underdanighet, og det maskuline til styrke, handlekraft, vitalitet, rasjonalitet og autoritet, vil det kanskje være større rom for sykdommer av denne typen. Slike fortolkningsrammer og kjønnsforståelser fortoner seg riktignok som anakronismer for de fleste av oss i dag, men lever ikke desto mindre $\mathrm{i}$ beste velgående som dype kulturelle og mentale strukturer innenfor enkelte felter og miljøer, også innenfor kulturens generelle forestillingsunivers og i deler av medisinen, som i et historisk perspektiv har fastholdt et bilde av kvinnen som svak og naturlig begrenset av sin kropp.

Klorosens historie illustrerer alt dette, men også at det ikke er et enkelt en-til-enforhold mellom moderne biomedisinske kategorier og sykdomskategorier fra fortiden. Snarere illustrerer klorosen historie at diagnoser er dynamiske begreper som også endres i relasjon til kulturelle og sosiale faktorer. Vi skal ikke glemme at klorose kunne ha dramatiske manifestasjoner. Så sent som i 1908 kan vi dessuten lese at klorosen kunne skjule en mulig tuberkulose og at denne underdiagnostiseringen spesielt gjaldt unge kvinner. Det vil si at når man treffer på et kasus som oppviser alle klorosens symptomer, deriblant den slående blekheten, men med normale blodverdier «[...] saa vil det gjerne være snakk om at en tuberkulose er tilstede» (17), en sykdom, også innskrevet $\mathrm{i}$ ansiktet i form av en farge.

\section{Oppgitte interessekonflikter: Ingen}

\section{Litteratur}

1. Potain P. Klorosens diagnostik. Norsk Mag Lægevidensk 1892: 675

2. Mercer CG, Wangensteen SD. Consumption, heart-disease, or whatever: Clorosis, a heroine's illness in The Wings of the Dove. J Hist Med Allied Sci 1985; 40: 259-85.

3. Johannisson K. Det mørke kontinentet. Kvinner. sykelighet og kulturen rundt århundreskiftet. Oslo: Aventura, 1996: 128-34.
4. Showalter E. The female malady. Women, mad ness, and English culture, 1820 -1980. London: Virago Press, 2001

5. Chlorosis, behandlet ved Eidsvoldsbadet $\mathrm{V} 306, \mathrm{VI}$ 338, VIII 276, XII 353, behandlet ved Grefsen Vandkuranstalt XV 113, XVIII 364, behandlet ved St. Olafs Kildens Bad, XIII 473. Norsk Mag Lægevidensk 1847-1870.

6. Lund A. De Norske Kursteders Udvikling og Kurmidle. Kristiania: Alb. Cammermeyer, 1880: 81

7. Vedeler BC. Lærebog om Kvindens Sygdomme. Kristiania: Alb. Cammermeyer, 1875: 407-9.

8. Bull E. Om kvindens helbred. Foredrag i Norsk kvindesags-forening, 12 feb. 1886. Kristiania: Norsk kvindesags-forening, 1886: 16.

9. Madsen S. Om klorose og dermed beslægtede sygdomme. Bergen: Johan Griegs forlag, 1896.

10. King $H$. The disease of virgins, Green sickness, chlorosis and the problems of puberty. London: Routledge, 2004: 19

11. King H. Hippocrates' woman. Reading the female body in Ancient Greece, London: Routledge, 1998 188-204.

12. Klorosens ætiologi, patagonese og terapi. Norsk Mag Lægevidensk 1881: 533

13. Johannisson K. Medicinens öga. Sjukdom, medicin och samhälle - historiska erfarenheter. Stockholm: Nordstedts, 1990: 117-22.

14. Shorter E. A history of women's bodies. Piscataway, NJ: Transaction Publishers, 1991: 247-54

15. Wailoo K. Drawing blood. Technology and disease identity in twentieth-century America. Baltimore, MD: The Johns Hopkins University Press, 1997. $17-45$

16. Guggenheim KY. Chlorosis: The rise and disappearance of a nutritional disease. J Nutr 1995; 125: $1822-5$

17. Tue K. Oversigter og uddrag. Norsk Mag Lægevidensk 1908: 1026.

Manuskriptet ble mottatt 30.9. 2009 og godkjent 5.11. 2009. Medisinsk redaktør Anne Kveim Lie. 